\title{
Discrepant Story Task: Instrumento utilizado para explorar estrategias narrativas en el maltrato entre iguales
}

\author{
Smorti, A. ${ }^{1}$ \\ Ortega-Rivera, J. ${ }^{2}$ \\ $y$ \\ Ortega, R. ${ }^{3}$ \\ ${ }^{1}$ Departamento de Psicología, Universidad de Florencia \\ (Florencia) \\ ${ }^{2}$ Dpto. de Psicología Evolutiva y de la Educación, Universidad de Sevilla \\ (Sevilla) \\ ${ }^{3}$ Departamento de Psicología, Universidad de Córdoba \\ (Córdoba)
}

\section{Italia y España}

smortian@psico.unifi.it 


\section{Resumen}

El principal objetivo de este trabajo es describir un instrumento diseñado para el estudio de los procesos cognitivos que están implicados cuando las personas interpretan los acontecimientos sociales (Discrepant Story Task - DST; Smorti, 2004). En concreto, este instrumento analiza los procesos narrativos de interpretación que un observador utiliza ante historias progresivas y regresivas. Tres estudios diferentes se han desarrollado utilizando DST en cuatro muestras de adolescentes implicados en bullying (agresores, victimas y controles) de Canadá, Italia y España. Los estudios han puesto de relieve cómo los adolesentes utilizan diferentes strategias narrativas para interpretar las historias progresivas y regresivas. En las historias progresivas, los participantes tienden a utilizar la atribución interna, mientras que en las historias regresivas utilizan más la atribución externa. Por lo que respecta al bullying, de los resultados se han extraido diferencias entre agresores de los diferentes países. Los resultados subrayan las ventajas de utilizar DST en el anáisis de la compresión social de historias progresivas y regresivas de los chicos y chicas agresores así como en el análisis de las diferencias crosculturales en términos de cognición social.

Keywords: Bullying, estrategias narrativas, historias progresivas, historias regresivas, instrumento narrativo. 


\begin{abstract}
The main aim of this contribution is to describe an instrument devised to study some of the cognitive processes that occur when people interpret social events (Discrepant Story Task - DST; Smorti, 2004). In particular, this instrument analyses the narrative processes of interpretation used by an observer when witnessing progressive and regressive stories. Three different studies have been developed using DST in four samples of adolescents from Canada, Italy and Spain, involving bullies, victims and control participants. Results showed that adolescents used different narrative strategies to interpret regressive and progressive stories. For progressive stories, adolescents tended to use internal attribution, while for regressive stories adolescents used more external attribution. Specifically for bullying, differences among bullies from different countries appeared. Results showed the advantages of using DST to study bullies' social understanding of progressive and regressive stories and also to analyse crosscultural differences in social cognition.
\end{abstract}

Keywords: Bullying, narrative strategies, progressive stories, regressive stories, narrative instrument. 


\section{Introduction}

\section{Bullying as an unbalanced aggressive routine}

Bullying is a serious form of aggressive and abusive peer interaction. It is usually defined by a minimum of three main criteria: 1) social interaction between a child or a group of children (the "bullies") who intentionally cause harm to another child or to a group of children (the "victims"); 2) a relationship based on an imbalance of physical, psychological, or social power, i.e., the bully is stronger or is perceived to be stronger than the victim; and 3) the aggressive and imbalanced interaction occurs repeatedly over time (Smith \& Brain, 2000).

These characteristics show that bullying can be considered an asymmetric context of peer interaction that endangers the psychological and social development of its protagonists (Pepler \& Rubin, 1991). In this sense, we assume that bullying is an interactive dynamic maintained over time, becoming a daily social routine for all that are involved in it. Nevertheless, bullying should not be identified exclusively as just a routine of actions; the social construction of knowledge should be considered as well. This social construction depends on how each person experiences bullying. The ones who always impose their will do not have the same kind of social knowledge as those classmates who are always suffering such impositions. Due to that, we define bullying as a social routine based on a social-cognitive pattern of domination and submission (Ortega, 1998a). However, this social knowledge is not exclusive to each role (victim or aggressor), but also concerns the shared knowledge that grows inside the group. In that way, bullying can be seen as a "Peer Culture" (Corsaro \& Eder, 1990; Ortega \& Mora-Merchán, 1996), where children in a group have stable behavior and are guided by rules and values that have been more or less explicitly managed by all of them.

The large body of existing research has investigated both social and cognitive aspects of bullying (Cairns, Cairns, Neckerman, Gest \& Gariepy, 1998; Fonzi, 1997). Bullies are more likely than their non-aggressive peers to experience antisocial problems (Olweus, 1993; Farrington, 1995; Coie \& Dodge, 1998). Some studies have found that bullies and victims tend to erroneously interpret ambiguous situations (Smith, Bowers, Binney \& Cowie, 1993). In bullying situations, bullies tend to attribute happy emotions to aggressors (Boulton \& Underwood, 1992). They also tend to have a generally poor awareness of their victims' feelings, 
claiming that it is the victim him/herself who provokes bullying acts (Olweus, 1993; Randall, 1997), and, due to that, lack empathy towards the victims (Eslea \& Smith, 1994). Bullies present difficulties in understanding the negative consequences of their actions (Dodge \& Crick, 1990; Dodge \& Frame, 1982; Dodge, Petit, McCladkey \& Brown, 1986). This may be because they have been defined as egocentric (Menesini, Sánchez, Fonzi, Ortega, Costabile \& LoFeudo, 2003). On the other hand, some studies have found that bullies have a strong ability to understand others' minds, but are unable to feel what others feel (Sutton, Smith \& Swettanham, 1999a; 1999b). In the case of Victims, they have difficulty recognizing emotions in other peers (Ciucci \& Fonzi, 1999) and present a high sense of moral and personal responsibility (Menesini et al, 2003), although tending to blame themselves about the situation in which they live every day at school (Olweus, 1993). Victims, as opposed to bullies, are seen as lacking assertiveness and the required social skills needed for group entry (Slee, 1993; Smith, Bowers, Binney \& Cowie, 1993). In relation to their coping strategies, they present difficulties in reacting when they receive aggressions from other peers or have to request help (Menesini, Fonzi, Sánchez \& Ortega, 2000; Ortega, Kulis \& Ortega-Rivera, 2001).

However, the majority of these explicative studies have been focused on sociopersonal characteristics of bullies and victims in terms of their competence and abilities, without including analysis of their mental representation. In this regard, we defend the importance of understanding their social knowledge of the bullying routine and how they think about what they are experiencing.

In a study on bullies' and victims' abilities to solve puzzling stories involving peer interaction episodes, Smorti and Ciucci (2000) found that bullies did better than victims in solving stories, shown by their use of mental verbs and analysis of the story protagonists' mental states. In another study (Smorti, Ortega, Ortega-Rivera \& Pagnucci, 2001) we asked Italian and Spanish bully and control groups to write autobiographical accounts of bullying and friendship episodes. Both in Spanish and in Italian samples, bullies wrote stories in which the main event (being bullied, bullying others and friendship acts) was less contextualised than in the stories written by control subjects (that is, they devoted less attention to describing the main characters and the starting situations). 
Our approach to the problem is based on a narrative frame of reference and is aimed mainly at understanding what strategies bullies and victims use when they are asked to interpret social events. Narrative research (Amsterdam \& Bruner, 2000; Bruner, 1990; Bruner, 1996; Gergen \& Gergen, 1988; Hermans \& Kempen, 1993 Polkigorne, 1988; Sarbin, 1986; Smorti, 2003) has demonstrated that stories serve as models for interpreting human actions. In fact, stories dealing fundamentally with human interactions are similarly organized diachronically, and are constructed based on a narrative pentad, consisting of people, actions, intentions, instruments, and scenes (Burke, 1945). People continually generate stories in an effort to structure and make sense of the events in their lives; and given that stories pertain essentially to human affairs and actions, the narrative thought producing them can be considered particularly well-suited to the interpretation of social interactions.

The main features of bullying, as outlined in this introduction, suggest that bullying can be considered a routine in which the persecutor and the victim play two complementary roles. This means that they share the same situation but have different means/goal strategies. When children are the source or the target of school bullying, the implication is that they play different roles in school routines and that they are therefore familiar with the various scripts these settings involve. Moreover, since this script knowledge influences how bullies and victims interpret events, we can assume that they reconstruct and interpret social interactions in different ways. Hence, since scripts are cognitive elaborations of routines (Nelson, 1996), we hypothesise that being in different routines leads children to narrate events based on different scripts.

\section{The Rationale of the Discrepant Story Task (DST)}

In this study we aimed to present an instrument (DST - Smorti, 2004) devised to study narrative strategies people construct when they have to interpret incongruent events. The rationale of this instrument is based on two main aspects of narration: narrative incongruence and the interpretation of incongruence.

1. Narrative incongruence is an apparent violation of coherence and of canonicity in the story. Of course, incongruities also occur in social life and just like in everyday life, as in 
stories, incongruities can take on different forms. There are two possible social processes that are theoretically and empirically important in this context: progressive and regressive processes (see Gergen \& Gergen, 1986). Progressive incongruent processes are those in which an improvement occurs in a peer relationship (for instance, when an aggressive relationship is violated by a prosocial act). Regressive incongruent processes are those in which the relationship deteriorates (for instance, when a prosocial relationship is violated by an aggressive act).

2. The interpretation of social incongruence can be defined as people's effort to create stories to confer congruence on incongruent situations (Bruner, 1990; Amsterdam \& Bruner, 2000). While making up narratives in order to restore coherence to the situation, people imagine possible events and antecedents that are not overtly expressed. As narrative scholars have theorised (Labov, 1997), this requires the use of a sort of personal theory of causality. Usually this theory takes into account: (a) the particular notion of Agency (Bruner, 1998a) that the observatory/narrator subject has, i.e., who is the Agent of the antecedents? How responsible is the protagonist for what he/she does? This also involves a conception about the situation and its role in determining the protagonist's acts. (b) The use of actions or mental states (action scenarios or consciousness scenarios, according to Bruner), include the various signals of subjectivity, such as emotion, affect, thoughts, etc. (Bruner, 1998b). (d) A third important aspect of, determining antecedents, for example, concerns social attitudes, i.e., the purpose of the action, and its hostile or prosocial nature. If we consider this theory of causality, based on Agency, situations, mental states, actions and purposes, it seems very close to what Kenneth Burke (1945) conceptualised as narrative pentad.

\section{Description of the Instrument}

\section{Structure}

The Discrepant Story Task (DST) consists of six short stories presented in either one of two versions, based on the student's gender. The stories deal with themes of social interaction between two peers--a protagonist and a partner--and consist of two parts. The first part of each story describes a typical behavioural scheme (a script) enacted by the protagonist in front of his or her partner at school. The second part (the incongruent event) is described in the text and illustrated by a cartoon (see the Story Texts and Cartoon Examples in the Appendix) and 
describes an episode in which the protagonist violates the script in some way. Story protagonists are operatively defined as the story's more salient of the two characters; protagonists result more salient because the stories describe their typical behavior as well as their incongruent acts. Partners are defined as the characters to whom the protagonist's incongruent act was directed.

Both the stories and cartoons are devised so that students can easily relate them to their everyday experiences. The stories vary systematically as to the type of social behaviorprosocial, aggressive, or neutral - portrayed in the script and in the incongruent event. Both the script and the incongruent event behavior vary according to these three types. The six stories are constructed to represent two different types of processes that can occur in peer relationships: progressive or regressive changes. In the progressive stories, aggressive behavior changed to either neutral or prosocial behavior, and neutral behavior changed to prosocial behavior. Therefore, the progressive stories portrayed three varieties of improvement processes possible in a depicted peer relationship: Aggressive-Prosocial (A-P), Neutral-Prosocial (NP), Aggressive-Neutral (A-N). Conversely, in regressive stories, neutral or prosocial behavior changed to aggressive behavior or prosocial behavior changed to neutral behavior, resulting in three possible varieties of deterioration processes in the depicted relationship: ProsocialAggressive (P-A), Prosocial-Neutral (P-N), Neutral-Aggressive (N-A) (See figure 1). The task instructions ask participants to explain the contradiction between the story's two parts (i.e., between the past script and the current incongruent act).

Figure 1: Progressive and Regressive Incongruent Stories

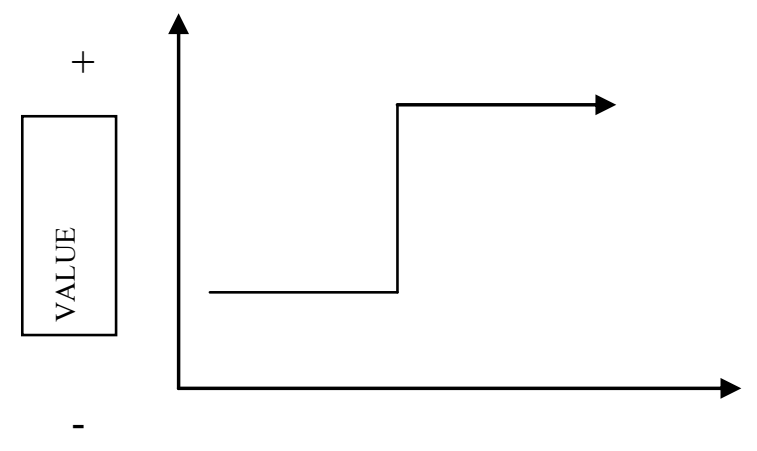

TIME

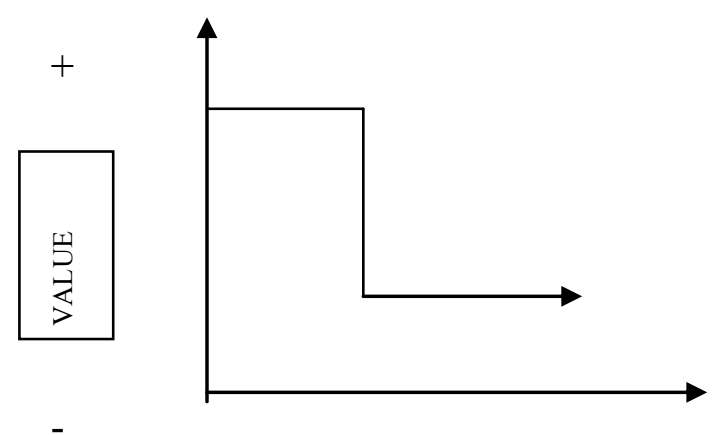

TIME 


\section{Administration Procedure}

In a school the test can be administered by teachers collectively during class hours, and the stories and cartoons are presented in a booklet. Students are told that they are taking a "serious" test, which is aimed at examining students" explanation of different types of behavior and problems that can occur in class. The teacher first reads a warm-up story to help the students understand the nature of the task. The students are then asked to read each of the six stories silently, to imagine what happened (why the protagonist behaved the way she or he had), and then to write a brief story about it in a provided space. It is emphasized that there are no right or wrong answers. The students usually take about 30-40 minutes to complete the task.

Given that the task is devised to assess a type of strategy, rather than a specific proficiency, it is assumed that the students' responses in the narrative task will not correlate linearly with their linguistic skills or intelligence. It is likely, however, that poor linguistic skills (poor writing skills and/or self-expression difficulties) or attention deficiencies can negatively affect the answers of students with these types of problems. Therefore, to avoid the confusion such deficits can produce, the teachers should sort out those students with linguistic, cognitive and/or social skill impairments (e.g. social instability, attention problems, low IQ, etc.).

\section{$\underline{\text { Analysis }}$}

Protocols are analyzed to identify the narrative strategies used by participants in order to interpret the incongruence. Narrative strategies are defined as the way in which the subject accounts for the incongruence, based on the type of story he/she tells when describing the antecedent event. Two elements are analyzed: antecedent event attribution and protagonist's social attitude attribution.

Antecedent Event Attribution. Four main types of response strategies are distinguished: Internal cognitive, Internal Emotional, Internal Intentional, and External. Also, a Total Internal Strategy score is computed. Internal Cognitive responses include cognitive mental verbs, which are verbs or predicates referencing thoughts or beliefs, such as think, believe, or remember (e.g., "A" thought that his classmates should do their homework by themselves, see P-A story in the appendix). Internal Emotional responses include mental verbs or predicates 
indicating feelings or emotions, such as anger, fear, or love (e.g., "A" was upset). Internal Intentional responses include mental verbs indicating plans or intentions and reflect the deliberate nature of the discrepant act. In other words, the protagonist is seen as someone in control of his/her actions (e.g., "A" was just trying to be nice to "B"; "A" liked to trick "B"). In the External response strategy, the antecedent is attributed to some aspect of the external physical context or the protagonist's social environment, such as his/her classmate or other people (e.g., the day before, "B" had given "A" his snack", see A-P story in the appendix). In these cases, the protagonist's incongruent act is considered to be caused by external forces and the protagonist's intention is denied or at least mitigated. The coding scheme also includes intermediate values (e.g., antecedents that were both internal and external to the protagonist), though this type of answer is rare.

Attribution of Social Attitude. The protagonists' attitude towards their companions is classified as hostile, prosocial or neutral. The protagonist's attitude is considered hostile if, according to the participant's interpretation, the protagonist means to accomplish a hostile goal (against the classmate). The protagonist's attitude is considered prosocial if, according the participant's interpretation, the protagonist means to accomplish a prosocial goal (for the classmate). The protagonist's attitude is considered to be neutral when it does expresses no particular attitude, neither hostile nor prosocial.

It should be noted that antecedent attributions and social attitude attributions are theoretically independent of each other. A participant may justify the protagonists' aggressive act and, at the same time, not deny the protagonist's aggressive act. For example, "A hit B because B had spread rumors about him." (see N-A story in the appendix). Here, the protagonist's act is somehow justified, but the hostile attitude is not denied.

Subjects' answers to each story are analysed with the coding scheme described above and transformed into nominal variables (presence of item $=1$; absence $=0$ ). Based on the story type (progressive or regressive), the nominal variables are then summed and analysed as quantitative variables, the values of which can vary from 0 to 3 (absence of the item in all three stories of the same type, presence in all of them). Variables without a normal distribution are later transformed into logarithmic variables and normalised, according to Levene's procedure. 


\section{Method}

This instrument was used on different samples and after various inquiries. We discuss its outcomes in two successive sections.

\section{Differences Between Progressive and Regressive Stories}

We applied DST on five different samples. In Smorti, McKeough, Ciucci \& Misfeld (1999) we examined a Canadian sample from Calgary ( $\mathrm{N}=89,46$ boys and 43 girls) consisting of 50 fourth grade early adolescents (mean age 9 years) and 39 seventh grade early adolescents (mean age: 12 years) and an Italian sample $(\mathrm{N}=117,46$ boys and 71 girls) from Florence, consisting of 59 fourth grade early adolescents (mean age 9 years ) and 58 seventh grade early adolescents (mean age: 12 years).

In Smorti, Ortega-Rivera, Ortega \& Pagnucci (2005) we examined an Italian sample from Florence ( $\mathrm{N}=143,82$ boys and 61 girls) that consisted of 54 fifth grade early adolescents (mean age: 11 years) and 89 sixth grade early adolescents (mean age: 12 years) and a Spanish sample from Seville ( $N=117,77$ boys and 40 girls) that consisted of 33 fifth grade early adolescents (mean age: 11 years), and 84 sixth grade early adolescents (mean age: 12 years).

In Smorti (2004) we examined a Florentine sample of 558 students: 284 boys and 274 girls from two middle schools located in the city of Florence, Italy. The students' ages ranged from 12 to 14 years of age (mean age $=12.9$ years).

\section{Table 1: Narrative Strategies from Samples Drawn from the Canadian, Spanish and Italian Population}

\begin{tabular}{|c|c|c|c|c|c|c|}
\hline & & $\begin{array}{l}\text { CANADA } \\
\text { Calgary (1) }\end{array}$ & $\begin{array}{c}\text { ITALY } \\
\text { Florence (1) }\end{array}$ & $\begin{array}{c}\text { SPAIN } \\
\text { Seville (2) }\end{array}$ & $\begin{array}{c}\text { ITALY } \\
\text { Florence (2) }\end{array}$ & $\begin{array}{c}\text { ITALY } \\
\text { Florence } \\
(3) \\
\end{array}$ \\
\hline $\begin{array}{c}\text { Narrative } \\
\text { Strategy }\end{array}$ & $\begin{array}{l}\text { Type of } \\
\text { Story }\end{array}$ & Mean \% & Mean \% & Mean fr. & Mean fr. & Mean fr. \\
\hline $\begin{array}{l}\text { Internal } \\
\text { cognitive }\end{array}$ & Progressive & $\begin{array}{c}75.2 \\
(27.7)\end{array}$ & $\begin{array}{c}72.8 \\
(28.0)\end{array}$ & $\begin{array}{l}2.39 \\
(.71)\end{array}$ & $\begin{array}{l}2.16 \\
(.84)\end{array}$ & $\begin{array}{l}2.39 \\
(.88)\end{array}$ \\
\hline $\begin{array}{l}\text { Internal } \\
\text { emotional }\end{array}$ & Progressive & $\begin{array}{c}14.4 \\
(22.1)\end{array}$ & $\begin{array}{c}19.5 \\
(25.7)\end{array}$ & $\begin{array}{c}.26 \\
(.53)\end{array}$ & $\begin{array}{c}.46 \\
(.68)\end{array}$ & $\begin{array}{l}1.05 \\
(.94)\end{array}$ \\
\hline
\end{tabular}




\begin{tabular}{|c|c|c|c|c|c|c|}
\hline $\begin{array}{l}\text { Internal } \\
\text { intention- } \\
\text { al }\end{array}$ & Progressive & $\begin{array}{c}80.9 \\
(26.4)\end{array}$ & $\begin{array}{c}70.8 \\
(27.8)\end{array}$ & & & \\
\hline $\begin{array}{l}\text { Total } \\
\text { internal }\end{array}$ & Progressive & $\begin{array}{c}89.6 \\
(19.3)\end{array}$ & $\begin{array}{c}92.3 \\
(23.4)\end{array}$ & $\begin{array}{l}2.65 \\
(.53)\end{array}$ & $\begin{array}{l}2.53 \\
(.68)\end{array}$ & $\begin{array}{c}2.6 \\
(.75) \\
\end{array}$ \\
\hline External & Progressive & $\begin{array}{c}10.4 \\
(19.3)\end{array}$ & $\begin{array}{c}11.8 \\
(20.4)\end{array}$ & $\begin{array}{l}.11 \\
(.34)\end{array}$ & $\begin{array}{l}.25 \\
(.48)\end{array}$ & $\begin{array}{l}.14 \\
(.39)\end{array}$ \\
\hline $\begin{array}{l}\text { Internal } \\
\text { cognitive }\end{array}$ & Regressive & $\begin{array}{c}29.7 \\
(24.4)\end{array}$ & $\begin{array}{c}17.1 \\
(25.4)\end{array}$ & $\begin{array}{l}1.01 \\
(.90)\end{array}$ & $\begin{array}{c}.80 \\
(.76)\end{array}$ & $\begin{array}{l}1.35 \\
(.97)\end{array}$ \\
\hline $\begin{array}{l}\text { Internal } \\
\text { emotional }\end{array}$ & Regressive & $\begin{array}{c}35.4 \\
(27.9)\end{array}$ & $\begin{array}{c}40.5 \\
(32.6)\end{array}$ & $\begin{array}{l}1.08 \\
(.88)\end{array}$ & $\begin{array}{l}1.01 \\
(.84)\end{array}$ & $\begin{array}{l}.95 \\
(.88)\end{array}$ \\
\hline $\begin{array}{l}\text { Internal } \\
\text { intention- } \\
\text { al }\end{array}$ & Regressive & $\begin{array}{c}40.3 \\
(31.2)\end{array}$ & $\begin{array}{c}14.2 \\
(21.1)\end{array}$ & & & \\
\hline $\begin{array}{l}\text { Total } \\
\text { internal }\end{array}$ & Regressive & $\begin{array}{c}65.2 \\
(30.2) \\
\end{array}$ & $\begin{array}{c}57.5 \\
(37.5) \\
\end{array}$ & $\begin{array}{l}2.09 \\
(.89)\end{array}$ & $\begin{array}{l}1.80 \\
(.91)\end{array}$ & $\begin{array}{c}1.8 \\
(.75) \\
\end{array}$ \\
\hline External & Regressive & $\begin{array}{c}34.8 \\
(30.2)\end{array}$ & $\begin{array}{c}52.7 \\
(31.0)\end{array}$ & $\begin{array}{c}.76 \\
(.82)\end{array}$ & $\begin{array}{l}1.01 \\
(.89)\end{array}$ & $\begin{array}{r}.80 \\
(.83) \\
\end{array}$ \\
\hline
\end{tabular}

1) McKeough A., Smorti A., et al. 1999 ,

2) Smorti, Ortega, Ortega, Pagnucci, 2005

3) Smorti, 2004

Note: In McKeough, Smorti et al. (2000) percentages of each strategy on total number of stories was used $(\min =0, \max =100)$, in Spain-Italy research row frequency was used $(\min =0, \max =3)$.

In Smorti, Ortega, Ortega, Pagnucci (2005) and in Smorti (2004) internal intentional was considered together with internal cognitive.

Table 1 clearly shows how early adolescents from the four different samples used internal cognitive responses in progressive stories more than in regressive stories and external responses in regressive stories more than in progressive stories. Moreover, in Smorti, McKeough, Ciucci \& Misfeld (1999) and in Smorti, Ortega-Rivera, Ortega \& Pagnucci (2005) internal emotional responses were also used more in regressive stories than in progressive stories. Finally, in Smorti, Ortega-Rivera, Ortega \& Pagnucci (2005) internal intentional responses were used more in progressive stories than in regressive ones.

However, cultural differences emerged as well. In the Italy-Spain comparison, in progressive stories, Italian early adolescents used external strategies $(F=7.14, p<.01)$ more than their Spanish counterparts did. Also, the Italian early adolescents used internal cognitive responses $(F=6.04, p<.01)$ and internal emotional responses $(F=7.14, p<.01)$ less than Spanish ones did. In regressive stories, Italian early adolescents used external strategies $(\mathrm{F}=5.26$, $\mathrm{p}<.05)$ more and internal cognitive responses $(\mathrm{F}=4.2, \mathrm{p}<.05)$ less than their Spanish counterparts. 
In the Italy-Canada comparison, Italian early adolescents used internal intentional responses in progressive stories $(\mathrm{F}=6.86 \mathrm{p}<.01)$ more than the Canadians and, in regressive stories, used more external responses $(\mathrm{F}=16.27, \mathrm{p}<.001)$. Also, Italian early adolescents used less internal cognitive responses $(\mathrm{F}=28.02, \mathrm{p}<$. 001), internal responses $(\mathrm{F}=13.8 ; \mathrm{p}<$. $001)$ and intentional responses $(\mathrm{F}=52.7 ; \mathrm{p}<001)$ than the Canadians.

Overall these results show how Italian early adolescents use more external strategies especially when they have to interpret regressive stories. In Smorti, McKeough, Ciucci \& Misfeld (1999) and in Smorti, Ortega-Rivera, Ortega \& Pagnucci (2005), possible cultural aspects of these differences are discussed.

Table 2: Social Attitudes in Four Samples Drawn from the Spanish, Canadian, and Italian Population

\begin{tabular}{|l|l|c|c|c|c|}
\hline & \multicolumn{1}{|c|}{$\begin{array}{c}\text { CANADA } \\
\text { Calgary }\end{array}$} & $\begin{array}{c}\text { ITALY } \\
\text { Florence (1) }\end{array}$ & $\begin{array}{c}\text { SPAIN } \\
\text { Seville (2) }\end{array}$ & $\begin{array}{c}\text { ITALY } \\
\text { Florence (2) }\end{array}$ \\
\hline $\begin{array}{l}\text { Protagonist's } \\
\text { attitude }\end{array}$ & $\begin{array}{c}\text { Type of } \\
\text { story }\end{array}$ & Mean \% & Mean \% & Mean Fr & Mean Fr \\
\hline Hostile & Progressive & $\begin{array}{c}19.9 \\
(22.2)\end{array}$ & $\begin{array}{c}12.0 \\
(18.7)\end{array}$ & $\begin{array}{c}.25 \\
(.50)\end{array}$ & .24 \\
& & 65.2 & 63.5 & 2.25 & 1.7 \\
\hline Prosocial & Progressive & $(26.1)$ & $(28.2)$ & $(.73)$ & $(.78)$ \\
\hline Hostile & Regressive & 70.8 & 65.2 & 2.21 & 1.64 \\
& & $(29.8)$ & $(28.4)$ & $(.80)$ & $(.85)$ \\
\hline Prosocial & Regressive & 1.9 & 2.6 & .04 & .09 \\
& & $(7.8)$ & $(8.9)$ & $(.21)$ & $(.29)$ \\
\hline
\end{tabular}

1) McKeough A., Smorti A., et al. 2000

2) Smorti, Ortega, Ortega, Pagnucci, 2005

Note: In Canada-Italy Research, percentages of each strategy on total number of stories was used $(\min =0$, $\max =100)$, in Spain-Italy research row frequency was used $(\min =0, \max =3)$.

In Smorti (2004) we did not consider social attitudes.

Table 2 shows results concerning social attitudes in the inquiries by Smorti, McKeough, Ciucci \& Misfeld (1999) and Smorti, Ortega-Rivera, Ortega \& Pagnucci (2005) (in Smorti, 2004, social attitudes were not analysed).

Overall, hostile attitudes were used in regressive more than in progressive stories; the reverse occurred for prosocial attitudes, which were attributed to the protagonist in progressive stories more than in regressive stories. Canadians used hostility in progressive stories 
more than Italians did, while Spanish early adolescents attributed a prosocial attitude to the protagonist in progressive stories and a hostile attitude in regressive stories more than the Italians did.

This data provides a general outlook on the way the Discrepant Story Task works. Early adolescents usually responded to these stories by interpreting the protagonist's acts according to a defending principle: stressing prosocial acts in their responses to progressive stories (using intentional and/or cognitive strategies) and mitigating aggressive acts in their responses to regressive stories (using external and/or emotional strategies). Participants did not mitigate the aggressive acts in regressive stories because they misinterpreted it. In fact, they attributed hostile attitudes to the protagonist in these stories. What they did is to interpret a hostile attitude according to a defending principle which justifies the aggressive act.

Moreover, the data stress the role of one's country, and therefore, possibly, the role of culture. This is not so strange since these stories entail a problem of the protagonist's responsibility, an issue firmly linked to cultural assumptions (see for instance the debate between individualistic-collectivistic or analytic-global (see, for instance: Hewstone, 1989).

\section{Research on Bullying}

Both regressive and progressive processes are relevant for bullies' and victims' experiences. Bullies and victims have different experiences and therefore, presumably, different interpretations of events concerning regressive processes. In fact, victims experience deterioration in relationships more than bullies do, and bullies rely on aggression to solve interpersonal problems, believing that their victims deserve to be bullied. We can speculate then that if bullies and victims play different roles in bullying routines (for instance, when a bully plays the role of agent who controls the victim and the victim plays the role of target who is controlled by the bully), bullies and victims should also construct different narratives, such as by attributing antecedents to bullying events differently.

The Discrepant Story Task (DST) was employed to test narrative strategies in bullies, victims and control Spanish and Italian samples. The sample was the same as the above described (Smorti, Ortega-Rivera, Ortega \& Pagnucci, 2005). Surveys on the diffusion of bullying as well as intervention projects had been previously conducted in both cities. In order to 
collect representative samples of pupils from different socioeconomic areas, the schools in both cities were selected according to their location in three different districts. The first district type was a housing estate characterised by low socioeconomic living standards. The second type was a residential district with a middle-to-high standard of living, and the third was an intermediate type, whose household heads were white-collar workers, artisans, and traders. In Florence, two schools were selected from each district, while in Seville, one school was selected from each district. The total sample in Florence consisted of 598 12-14 year-old pupils (girls $=258$, boys $=340$ ) attending the six selected schools. The Seville sample was composed of 704 12-14-year-old pupils (girls $=312$, boys $=392$ ) attending the three selected schools.

Participants involved in bullying episodes were identified by means of a peer nomination questionnaire (Ortega \& Ortega-Rivera, 1999), which identified different participant roles in bullying episodes. Children who were identified as bullies or victims, as well as a control group of participants, were included in the final sample (see Smorti, Ortega-Rivera, Ortega \& Pagnucci 2005 for procedure description). Teachers first rated children's language competence in order to verify their linguistic skills, and children who rated "below" grade level (i.e., more than one year below their current grade level at the time of testing) were not included in the final sample. The final Florence sample consisted of 143 pupils, i.e., 82 boys and 61 girls, 54 of whom were 11 years old and 89 of whom were twelve years old (Bullies $=51$, Victims $=47$, Control participants $=45$ ). The final Seville sample comprised 117 pupils, i.e., 77 boys and 40 girls, 33 of whom were 11 years old, and 84 of whom were twelve years old (Bullies = 42; Victims $=36$; Control $=39$ ). There were no significant age or role differences (bully, victim, and control) between the two samples. Both samples had more bully and control boys than bully and control girls.

The coding system consisted in distinguishing three main strategies (internal cognitive, internal emotional and external responses) and three types of social attitudes (prosocial, hostile and neutral) and coordinating them into seven unitary strategy x social attitude categories. Only the internal strategy was analysed for mental verbs and protagonists' attitudes. Therefore, the following strategy categories were analysed: a) internal cognitive prosocial, b) internal cognitive neutral, c) internal cognitive aggressive, d) internal cognitive (the sum of the above strategies), e) internal emotional prosocial, f) internal emotional neutral, g) internal 
emotional aggressive, h) internal emotional (the sum of the internal emotional strategies), i) internal (the sum of all internal cognitive and internal emotional strategies), and $\mathrm{j}$ ) external.

Inter-rater reliability among Italian and Spanish researchers was facilitated by their participation in the same bullying-prevention project: the "Training and Mobility of Researchers Project" on "The Nature and Prevention of Bullying". This project required young Italian and Spanish researchers to spend time working together in each other's countries; this particular aspect of the project contributed to a greater collaboration among researchers (for more details see the website: http://www.gold.ac.uk/tmr). The scoring system was first tested for its internal consistency, with inter-rater agreements calculated for both Spanish and Italian research teams. In all cases, Cohen's Kappa Coefficients varied from 0.70 to 0.80 and were thus considered satisfactory.

Firstly, we conducted various multivariate analyses to verify if Gender and/or Age had any significant effects on relations between Countries and Strategies and between Groups and Strategies. For both progressive and regressive stories, multivariate analyses of Gender $\mathrm{x}$ Role, Age x Role, Gender x Country, and Age x Country yielded no statistically significant differences. Since country differences were discussed previously, we will concentrate now only on group and country $\mathrm{x}$ group differences.

Table 3 and 4 show bullies, victims and control subjects for progressive and regressive stories.

TABLE 3 : Mean Scores (range 0-3) for Strategies x Social Attitudes in Progressive Stories (S.D. in brackets).

\begin{tabular}{|l|c|c|c|c|c|c|c|c|}
\cline { 2 - 10 } \multicolumn{1}{c|}{} & \multicolumn{4}{c|}{ Italy } & \multicolumn{4}{c|}{ Spain } \\
\hline & Bully & Victim & Control & Total & Bully & Victim & Control & Total \\
Strategy & Mean & Mean & Mean & Mean & Mean & Mean & Mean & Mean \\
& S.D & S.D & S.D & S.D & S.D & S.D & S.D & S.D \\
\hline Internal & 2.53 & 2.49 & 2.58 & 2.53 & 2.71 & 2.75 & 2.49 & 2.65 \\
& $(.73)$ & $(.69)$ & $.62)$ & $(.68)$ & $(.51)$ & $(.5)$ & $(.55)$ & $(.53)$ \\
\hline Internal cognitive hostile & .16 & .21 & .22 & .20 & .26 & .31 & .18 & .25 \\
& $(.42)$ & $(.46)$ & $.42)$ & $(.43)$ & $(.44)$ & $(.47)$ & $(.39)$ & $(.43)$ \\
\hline Internal cognitive & 1.41 & 1.36 & 1.53 & 1.43 & 1.81 & 1.78 & 1.69 & 1.76 \\
prosocial & $(.88)$ & $(.92)$ & $(.87)$ & $(.88)$ & $(.80)$ & $(.96)$ & $(.89)$ & $(.88)$ \\
\hline Internal cognitive neutral & .45 & .47 & .58 & .50 & .38 & .25 & .38 & .34 \\
& $(.61)$ & $(.62)$ & $(.62)$ & $(.61)$ & $(.49)$ & $(.44)$ & $(.59)$ & $(.51)$ \\
\hline Internal emotional hostile & .06 & .04 & 0 & .03 & .05 & 0 & 0 & .02 \\
& $(.24)$ & $(.20)$ & $(0)$ & $(.16)$ & $(.21)$ & $(0)$ & $(0)$ & $(.13)$ \\
\hline
\end{tabular}




\begin{tabular}{|l|c|c|c|c|c|c|c|c|}
\hline Internal emotional & .20 & .17 & .09 & .15 & .12 & .17 & .18 & .15 \\
prosocial & $(.45)$ & $(.43)$ & $(.29)$ & $(.40)$ & $(.33)$ & $(.45)$ & $(.45)$ & $(.41)$ \\
\hline Internal emotional & .25 & .38 & .20 & .28 & .09 & .05 & .05 & .07 \\
neutral & $(.48)$ & $(.68)$ & $(.40)$ & $(.54)$ & $(.30)$ & $(.23)$ & $(.22)$ & $(.25)$ \\
\hline External & .25 & .23 & .27 & .25 & .12 & .03 & .18 & .11 \\
& $(.48)$ & $(.48)$ & $(.49)$ & $(.48)$ & $(.39)$ & $(.17)$ & $(.39)$ & $(.34)$ \\
\hline
\end{tabular}

TABLE 4 : Mean Scores (range 0-3) for Strategies $x$ Social Attitudes in Regressive Stories (S.D. in brackets).

\begin{tabular}{|c|c|c|c|c|c|c|c|c|}
\hline \multirow[b]{2}{*}{ Strategy } & \multicolumn{4}{|c|}{ Italy } & \multicolumn{4}{|c|}{ Spain } \\
\hline & $\begin{array}{c}\text { Bully } \\
\text { Mean } \\
\text { S.D }\end{array}$ & $\begin{array}{l}\text { Victim } \\
\text { Mean } \\
\text { S.D }\end{array}$ & $\begin{array}{c}\text { Control } \\
\text { Mean } \\
\text { S.D }\end{array}$ & $\begin{array}{c}\text { Total } \\
\text { Mean } \\
\text { S.D }\end{array}$ & $\begin{array}{c}\text { Bully } \\
\text { Mean } \\
\text { S.D }\end{array}$ & $\begin{array}{c}\text { Victim } \\
\text { Mean } \\
\text { S.D }\end{array}$ & $\begin{array}{c}\text { Control } \\
\text { Mean } \\
\text { S.D }\end{array}$ & $\begin{array}{c}\text { Total } \\
\text { Mean } \\
\text { S.D }\end{array}$ \\
\hline Internal & $\begin{array}{l}1.55 \\
(.97)\end{array}$ & $\begin{array}{l}1.81 \\
(.85) \\
\end{array}$ & $\begin{array}{l}2.07 \\
(.84) \\
\end{array}$ & $\begin{array}{l}1.80 \\
(.91)\end{array}$ & $\begin{array}{l}2.40 \\
(.77)\end{array}$ & $\begin{array}{l}1.80 \\
(.95) \\
\end{array}$ & $\begin{array}{l}2.02 \\
(.87) \\
\end{array}$ & $\begin{array}{l}2.09 \\
(.89) \\
\end{array}$ \\
\hline Internal cognitive hostile & $\begin{array}{l}.10 \\
(.30)\end{array}$ & $\begin{array}{l}.25 \\
(.44)\end{array}$ & $\begin{array}{l}.22 \\
(.42)\end{array}$ & $\begin{array}{l}.19 \\
(.39)\end{array}$ & $\begin{array}{c}.81 \\
(.86)\end{array}$ & $\begin{array}{l}.39 \\
(.55)\end{array}$ & $\begin{array}{l}.54 \\
(.64)\end{array}$ & $\begin{array}{l}.59 \\
(.72)\end{array}$ \\
\hline $\begin{array}{l}\text { Internal cognitive } \\
\text { prosocial }\end{array}$ & $\begin{array}{l}.10 \\
(.30)\end{array}$ & $\begin{array}{l}.02 \\
(.15)\end{array}$ & $\begin{array}{l}.11 \\
(.32)\end{array}$ & $\begin{array}{l}.08 \\
(.27)\end{array}$ & $\begin{array}{l}.02 \\
(.15)\end{array}$ & $\begin{array}{c}.03 \\
(.17)\end{array}$ & $\begin{array}{c}.02 \\
(.16)\end{array}$ & $\begin{array}{l}.03 \\
(.16)\end{array}$ \\
\hline Internal cognitive neutral & $\begin{array}{c}.39 \\
(.72) \\
\end{array}$ & $\begin{array}{c}.55 \\
(.65)\end{array}$ & $\begin{array}{c}.67 \\
(.67)\end{array}$ & $\begin{array}{c}.53 \\
(.69) \\
\end{array}$ & $\begin{array}{c}.38 \\
(.54)\end{array}$ & $\begin{array}{c}.39 \\
(.60)\end{array}$ & $\begin{array}{c}.38 \\
(.63)\end{array}$ & $\begin{array}{c}.38 \\
(.58) \\
\end{array}$ \\
\hline Internal emotional hostile & $\begin{array}{l}.53 \\
(.81)\end{array}$ & $\begin{array}{c}.62 \\
(.74)\end{array}$ & $\begin{array}{l}.58 \\
(.62)\end{array}$ & $\begin{array}{l}.57 \\
(.73)\end{array}$ & $\begin{array}{l}1.05 \\
(.85)\end{array}$ & $\begin{array}{l}.69 \\
(.82)\end{array}$ & $\begin{array}{l}.90 \\
(.85)\end{array}$ & $\begin{array}{l}.89 \\
(.85)\end{array}$ \\
\hline $\begin{array}{l}\text { Internal emotional } \\
\text { prosocial }\end{array}$ & $\begin{array}{c}.02 \\
(.14) \\
\end{array}$ & $\begin{array}{c}0 \\
(0) \\
\end{array}$ & $\begin{array}{c}0 \\
(0) \\
\end{array}$ & $\begin{array}{l}.07 \\
(.08)\end{array}$ & $\begin{array}{c}0 \\
(0) \\
\end{array}$ & $\begin{array}{c}0 \\
(0) \\
\end{array}$ & $\begin{array}{c}0 \\
(0)\end{array}$ & $\begin{array}{c}0 \\
(0)\end{array}$ \\
\hline $\begin{array}{l}\text { Internal emotional } \\
\text { neutral }\end{array}$ & $\begin{array}{l}.43 \\
(.57) \\
\end{array}$ & $\begin{array}{l}.38 \\
(.53) \\
\end{array}$ & $\begin{array}{l}.42 \\
(.66) \\
\end{array}$ & $\begin{array}{c}.41 \\
(.58) \\
\end{array}$ & $\begin{array}{l}.14 \\
(.35) \\
\end{array}$ & $\begin{array}{l}.19 \\
(.40) \\
\end{array}$ & $\begin{array}{l}.18 \\
(.45) \\
\end{array}$ & $\begin{array}{l}.17 \\
(.40)\end{array}$ \\
\hline External & $\begin{array}{l}1.20 \\
(.98)\end{array}$ & $\begin{array}{l}.98 \\
(.85)\end{array}$ & $\begin{array}{c}.84 \\
(.80)\end{array}$ & $\begin{array}{l}1.01 \\
(.89)\end{array}$ & $\begin{array}{l}.55 \\
(.77)\end{array}$ & $\begin{array}{c}.97 \\
(.84)\end{array}$ & $\begin{array}{l}.79 \\
(.80)\end{array}$ & $\begin{array}{l}.76 \\
(.82)\end{array}$ \\
\hline
\end{tabular}

In progressive stories no differences emerged for internal strategies or for external ones. Across the three different groups, internal strategies were used more than external ones, internal cognitive strategies more than emotional ones, and prosocial attitudes more than hostile ones. This is consistent with the previous results so far discussed.

In regressive stories, a different situation appears. External strategies, strategies involving emotions and those involving hostile attitudes were used more in respect to progressive stories. Moreover, differences between groups emerged. In internal strategy responses, while the Italian victims and control groups $($ mean $=1.81$ and mean $=2.07)$ did not significantly differ from the Spanish ones $($ mean $=1.80$ and mean $=2.08)$, there 
were differences between the Spanish and Italian bully groups, since the Spanish bullies used internal strategies (mean $=2.40$ ) significantly more than the Italian bullies did $($ mean $=1.55)(\underline{T}=4.66$, D.F. $=91, \underline{p}<.01)$. Moreover, in the Italian sample, the difference in internal attribution was statistically significant $(\underline{\mathrm{F}}(2,140)=4.06, \underline{\mathrm{p}}<.05)$. The bully group (mean $=1.55$ ) used fewer internal strategies than the control groups did $($ mean $=1.81)($ Scheffè post hoc $\underline{p}<.05)$. Significant differences also emerged in the Spanish sample among roles $(\underline{\mathrm{F}}(2,117)=4.87 ; \underline{\mathrm{p}}<.01)$, but in this case bullies used more internal strategies $($ mean $=2.40)$ than victims did $($ mean $=1.81)($ Scheffè post hoc $\mathrm{p}<.01)$.

As for the internal cognitive strategy, Spanish bullies used it more than Italian bullies $\operatorname{did}(\underline{\mathrm{F}}(2,255)=4.28 ; \underline{\mathrm{p}}<05)$. Moreover, a Role difference emerged in the Italian sample, $(\underline{\mathrm{F}}$ $(2,140)=3.75 ; \underline{p}<.05)$ : the bully group relied significantly less on the internal cognitive strategy $($ mean $=.59)$ than the control group did $($ mean $=1)$ (Scheffè post hoc $\underline{p}<.05)$. No difference was found for the internal emotional strategy, neither between nor within Florence or Seville.

As for the internal cognitive hostile strategy, Spanish pupils used the internal cognitive hostile strategy more frequently than Italian pupils did. This difference was due mainly to the differences in bully groups: in the Italian sample, the internal cognitive hostile strategy was nearly absent, while in the Spanish sample it was the most frequently used strategy. Moreover, in the Spanish sample, the bully group (mean $=.81$ ) relied on the internal cognitive hostile strategy more than the victim group did (mean $=.39)(\underline{\mathrm{F}}(2,114)=3.60 ; \underline{\mathrm{p}}<.05 ;$ Scheffè post hoc $\underline{\mathrm{p}}<.05)$.

\section{Discussion}

The principle objective of this work is the empirical validation of the Discrepant Story Task (DST) as an instrument that allows us to study the strategies of interpretation that adolescents use to understand incongruent social situations. Our interest was centered on those adolescents who are implicated in situations of violence and, in particular, on the phenomenon of bullying. In order to fulfil this objective we performed empirical analyses on two fundamental aspects: differences between progressive and regressive stories, and comparison 
between bully, victim and control groups. Differences between progressive and regressive stories were assessed by three subsequent investigations. In the first one, we compared a sample of Canadian adolescents to a sample of Italian ones. In the second investigation, we compared a sample of Italian adolescents to a Spanish sample. In the third, we carried out a study about a sample of adolescent Italians.

In the comparison between progressive and regressive stories, a clear difference emerged between internal and external strategies. Subjects from the different samples show a tendency to use external strategies more when the incongruity is regressive, whereas when the incongruity is progressive, they tend to use internal strategies more. Internal strategies are also different in relation to the type of story (progressive or regressive). Internal cognitive and internal intentional strategies are used more in progressive stories and internal emotional strategies are used more in regressive stories.

How can we interpret these results? We know that in progressive stories, the protagonist's incongruent behavior (discrepant event) is positive or implies an improvement in the relation that he/she maintained with the script. This improvement is attributed to the protagonist by internal causes (mainly intentional or cognitive). On the other hand, in regressive stories, the incongruent behavior (discrepant event) is negative or implies a worsening of the relation with the partner (script). In this case, the negative behavior is attributed to external causes. These data show a general tendency that has already been found in other similar studies (Brooker, 2004; Cortazzi, 1993; Gergen \& Gergen, 1998). When one has a socially positive behavior, one tends to recognize the intention of the subject (responsibility), while when one's social behavior is negative, one tends to not totally attribute the intention to the subject. In that case, one's behavior has been produced by something that has happened in the subject's environment (justification).

In progressive and regressive stories, however, country differences emerged as well. In the comparison Calgary - Florence, Canadian students, in regressive stories, used internal cognitive and internal intentional strategies more, and used external strategies less than the Italians. In the progressive stories, Italian students used internal intentional strategies more than Canadians did. In the comparison between Seville and Florence, in the progressive stories, the Spanish students used more internal cognitive and internal emotional strategies, and used external strategies less than the Italian students did. In the regressive stories, this ten- 
dency was maintained and statistical differences in internal and external cognitive strategies appeared. The Spanish students used internal cognitive strategies more and external strategies less than the Italian students.

In summary, Italian adolescents tended to justify the protagonist's aggressive attitude in regressive stories more than Canadian and Spanish adolescents did.

In order to explore the differences between the narrative strategies of adolescents involved in bullying, we have used the DST in two samples pertaining to Italy and Spain. In particular, we have compared the narrative strategies of bullies, victims and control subjects in both countries.

After studying the group differences in depth, we found that the Italian and Spanish bullies were differentiated from other groups, but in opposite ways. In regressive stories, the Italian bullies were less internal and less internal cognitive than the victims and controls were, while the Spanish bullies were more internal, internal cognitive, and internal cognitive hostile than the victims were. Therefore, two distinct bully types seem to emerge: 1) bullies from the Spanish sample, who invent stories to explain how the protagonist's negative shift in regressive stories is caused by his or her hostile intentions or thoughts, and 2) bullies from the Italian sample, who seem to want to smooth over negative story shifts. They achieve this in three main ways: with fewer internal (therefore justifying) strategies, by using more emotional verbs (thereby attributing less controllability), and by attributing more neutral and fewer hostile intentions to the protagonists (thereby watering down any potential hostilities).

How can we interpret these differences found among Spanish and Italian bullies? We can use the concept of "positioning" (Bamberg, 1997) to make sense of these results. Positioning can be considered a psychologically applied version of the concept of perspective. It entails considering story-telling a conversational activity that varies in relation to how narrators position themselves in respect to their story characters and to their listeners (Bamberg, 1997). In this frame-of-reference we think that the Italian and Spanish students tend to take a different stance towards story protagonists, or, they position themselves differently.

Bullies from the two different countries assume a somehow more "radical" position (in comparison to the two other groups) when interpreting the protagonist's negative shift in re- 
gressive stories. In particular, the Florentine bullies assume a position that is "internal" to the protagonist. Given this position, they apparently do not attribute the actor's failures to internal causes (i.e., to the actor) but, rather, to external ones (to the situation). Due to that, they describe the protagonists less as people who intentionally commit negative acts, and their intentions are seen as less hostile. In other words, they take the perspective of the protagonist and adopt an interpretational style that defends the protagonist. Similar results have been found in a number of studies conducted on both adults and children (Normaneau \& Gobeil, 1998; Russell, 1982; Russell McAuly \& Tarico, 1987; Stipek \& DeCotis, 1988).

Conversely, the Seville bullies adopt a more "external" kind of position in respect to the story protagonists, as if they were evaluating someone different from themselves. They are likely to position themselves alongside the partner, against whom the protagonist's action is directed. When the protagonist's behavior is negative (in regressive stories) they attribute a hostile intention to the protagonist. Hence, the Spanish bullies act more similarly to what Dodge (Dodge \& Frame,1982) observed in aggressive boys, that is to say that aggressive boys, as opposed to non-aggressive boys, are more likely to attribute an ambiguous provocation to a peer's hostile intentions rather than to accidental peer behavior.

Therefore, the Italian and Spanish participants present two different strategies in interpreting regressive change, depending on the stance they take towards protagonists: they can either attribute regressive change to less internal causes or to neutral emotional states, or they can attribute it to intention or even to hostile intention. The Italian bullies have a tendency to justify the behavior of the protagonists by inventing other stories in which protagonists seem to be driven by external events. On the contrary, the Spanish bullies have a tendency to attribute responsibility to the protagonists and their behavior.

These results can be of great interest to teachers and all people dealing with the problem of bullying. Although bullying behaviour takes on similar characteristics in different countries, this phenomenon might be based on different cognitive processes of interpreting reality, as a function of how children "position" themselves in terms of social relations. This result is very important for intervention programs, especially for direct intervention between bullies and victims (for examples of intervention programs for empathy and assertiveness see: Ortega, 1998b; Smith \& Sharp, 1994). On the other hand, this approach could also be of great interest and help to psychologists and educators working on class conflict management. By 
training students in peer support and peer mediation (Cowie, 1999; Del Rey \& Ortega, 2001), increasing students' awareness of their own social interpretative strategies, and by working side by side with students in analyzing the possible motives underlying changes in peer behavior, teachers can facilitate the positive perception and interpretation of others as well as positive approaches to social interaction. Empathy programs (with aggressors) carried out interventions based on the emotional perspective that children have to take in order to modulate their relationships. Through training in peer support and peer mediation of defenders analyzing these social representations, we can know the important sociocognitive aspects that are basic to understanding bullying.

In conclusion, we have confirmed in different studies that the Discrepant Story Task (DST) is a good instrument to analyse social interpretations that adolescents produce when faced with social incongruence. We have found differences in terms of type of story (progressive vs. regressive), country (Italy vs. Canada and Spain), groups (bully vs. victim or control groups) and country x groups (Florentine bullies vs. Seville bullies). We have interpreted these differences in terms of positioning, and we believe that this interpretation must be taken into consideration in intervention projects on bullying. 


\section{References}

Amsterdam, A.G., \& Bruner, J. (2000). Minding the Law. Cambridge: Harvard University Press.

Bamberg, M. (1997). Positioning between structure and performance. Journal of Narrative and Life History, 7 (1-4), 335-342.

Boulton, M. J. \& Underwood, K. (1992). Bully/victim problems among middle school children. British Journal of Educational Psychology, 62, 73-87.

Brooker, C. (2004). The seven basic plots. London: Continuum.

Bruner, J. (1990). Acts of meaning. Cambridge MA: Harvard University Press.

Bruner, J. (1996). The culture of education. Cambridge MA: Harvard University Press.

Bruner, J. (1998a). A narrative model of self construction. In J.G. Snodgrass \& R. Thompson (Eds), New York Academy of Sciences. Annals. The Self-Across Psychology: Self Recognition, Self Awareness and Self Concept (pp. 145-161). New York: New York Academy of Sciences.

Bruner, J. (1998b). Narrative and Metanarrative in the construction of self. In M. Ferrari \& R.J. Stenberg (Eds.), Self-Awareness: its Nature and Development (pp. 308-331). New York: The Guilford Press.

Burke, K. (1945). A grammar of Motives. New York : Prentice-Hall.

Cairns, R.B., Cairns B.D., Necherman, H.J., Gest S,D. \& Gariepy, J.L. (1988). Social networks and aggressive behaviour: peer support or peer rejection? Developmental Psychology, 24 (6), 815-823.

Ciucci, E. \& Fonzi, A. (1999). La grammatica delle emozioni in prepotenti e vittime. [The grammar of emotions in bullies and victims.] In Fonzi, A. (Ed.), Il gioco crudele. Compagni vittime e compagni oppressori (pp. 27-38). Florence: Giunti.

Coie, J.D. \& Dodge, K.A (1998). Aggression and antisocial behaviour. In W. Damon W (Ed). Handbook of Child Psychology (pp. 779-862). New York: Wiley.

Corsaro, W. A. \& Eder, D. (1990). Children's peer cultures. American Review of Sociology, 16, 197-220.

Cortazzi, M.(1993). Narrative Analysis. London:Falmer Press

Cowie, H. (1999). Peers helping peers: interventions, initiatives and insights. Journal of Adolesce, 22, 433-436.

Del Rey, R. \& Ortega, R. (2001). El programa de ayuda entre iguales, en el contexto del proyecto Sevilla Anti-Violencia Escolar. [The peer help program, in the context of the Seville Anti-School Violence project.] Revista de Educación, 326, 297-310.

Dodge, K.A (1986). A social information processing model of social competence in children. In M. Perlmutter (Ed.), Minnesota Symposia on Child Psychology: Cognitive Perspectives on Children's Social and Behavioral Development, vol. 18 (pp. 77-125). Hillsdale NJ.: Erlbaum.

Dodge, K. A. \& Crick, N. R. (1990). Social information-processing bases of aggressive behavior in children. Personality and Social Psychology Bulletin, 16, 8-22.

Dodge, K.A. \& Frame, C.L. (1982). Social Cognitive and deficits in Aggressive Boys. Child Development 53, 620-635. 
Dodge, K.A., Pettit, G.S., McClaskey, C.L. \& Brown, M.M. (1986). Social competence in children. Monograph of Society for Research in Child Development, 51 (2, Serial No.213)

Eslea, M. \& Smith, P. K. (1994, june). Developmental trends in attitudes to bullying. Paper presented at the XIII Biennial Meetings of ISSBD, Amsterdam, Holland.

Farrington, D.P. (1995). Childhood aggression and adult violence: early precursors and later life outcomes. In D.J. Pepler \& K.H. Rubin (Eds), The Development and Treatment of Childhood Aggression (pp. 5-29). Hillsdale, N.J: Erlbaum.

Fonzi, A (Ed.) (1997). Il bullismo in Italia. Il Fenomeno delle Prepotenze a Scuola dal Piemonte alla Sicilia. [Bullying in Italy. The bully phenomenon in the Piemonte School in Sicily.] Florence: Giunti.

Gergen, K.J. \& Gergen, M.M. (1986). Narrative form and the construction of psychological science. In T.R. Sarbin (Ed.), Narrative Psychology, The storied nature of human conduct (pp. 22-44). New York: Praeger.

Hermans, H.J.M. \& Kempen, H.J.G. (1993). The dialogical Self: Meaning as movement. San Diego CA: Academic Press.

Hewstone, M. (1989). Causal attribution: from cognitive processes to collective beliefs. Cambridge, MA: Basil Blackwell.

Labov, W. (1997). Some further steps in narrative analysis. Journal of Narrative and Life History, 7 (1-4), 395-415.

Menesini, E., Fonzi, A., Sánchez, V. \& Ortega, R. (2005). Strategie di coping e valutazione degli esiti in un contesto di bullismo. [Coping and assessment strategies from responses in a bullying context.] Ressegna di Psicologia, 22 (2), 69-84.

Menesini, E., Sánchez, V., Fonzi, A., Ortega, R., Costabile, A. \& LoFeudo, G. (2003). Moral emotions and bullying: A cross-national comparison of differences between bullies, victims and outsiders. Aggressive Behavior, 29 (6), 515-530.

Nelson, K. (1996). Language in Cognitive Development. Cambridge: Cambridge University Press.

Normaneau, S. \& Gobeil, A. (1998). A developmental perspective on children's understanding of causal attributions in achievement-related situations. International Journal of Behavioural Development 22 (3), 611-632.

Olweus, D (1993). Bullying at School. What We Know and What We Can Do. Oxford: Blackwell.

Ortega, R. (1998a). Víctimas, agresores y espectadores de la violencia escolar. [Victims, bullyings and onlookers of school violence.] In R. Ortega (ed.), La convivencia escolar: qué es y cómo abordarla (pp. 37-50). Seville: Consejería de Educación y Ciencia de la Junta de Andalucía.

Ortega, R. (1998b). Trabajando con víctimas, agresores y espectadores de la violencia escolar. [Working with victims, bullies and onlookers of school violence.] In R. Ortega (ed.), La convivencia escolar: qué es y cómo abordarla (pp. 221-246). Seville: Consejería de Educación y Ciencia de la Junta de Andalucía.

Ortega, R., Kulis, M. \& Ortega-Rivera, J. (2001, February). The educational authority responses to bullying in schools: Telefono Amigos in Andalucia. Paper presented at the International Conference on Violence in Schools and Public Policies, Paris, France. 
Ortega, R. \& Mora-Merchán, J. A. (1996). El aula como escenario de la vida afectiva y moral. [The classroom as a scenario of affective and moral life.] Cultura y Educación. 3, $5-18$.

Ortega, R. \& Ortega-Rivera, J (1999). Peer nomination instrument. Unpublished manuscript.

Pepler, D. \& Rubin, K (Eds) (1991). The Development and Treatment of Childhood Aggression. Hillsdale, NJ: Erlbaum.

Polkinghorne, D.E. (1988). Narrative knowing and the human sciences. New York, NY: University of New York Press.

Randall, P. (1997). Adult bullying: Perpetrators and victims. London: Routledge.

Russell, D. (1982). The causal dimension scale: a measure of how individuals perceive causes. Journal of Personality and Social Psychology, 42, 1137-1145.

Russel, D, McAuly, E. \& Tarico, V. (1987). Measuring causal attributions for success and failure: a comparison of methodologies for assessing causal dimensions. Journal of Personality and Social Psychology, 52, 1248-1257.

Sarbin, T. (ed.) (1986). Narrative Psychology. New York: Praeger.

Slee, P.T. (1993). Bullying a preliminary investigation of its nature and the effects of social cognition. Early Child Development and Care, 87, 47-57.

Smith, P.K., Bowers, L., Binney, V., \& Cowie, H. (1993). Relationships of children involved in bully/victim problems at school. In S. Duck (Ed), Understanding Relationship Processes vol. 2: Learning about Relationships (pp. 184-212). Newbury Park: Sage.

Smith, P.K. \& Brain, P. (2000). Bullying in schools: Lessons from two decades of research. Aggressive Behaviour, 26, 1-9.

Smith, P.K. \& Sharp, S. (1994). School bullying. Insights and perspectives. London: Routledge.

Smorti, A. (2003). La Psicologia culturale. [Cultural Psychology.] Roma: Carocci.

Smorti A. (2004), Narrative strategies for interpreting stories with incongruent endings. Narrative Inquiry, 14(1), 163-189.

Smorti, A. \& Ciucci, E. (2000). Narrative strategies in bullies and victims in Italian schools. Aggressive Behaviour, 26, 33-48.

Smorti, A., McKeough A., Ciucci, E. \& Misfeld, D. (1999, September). Narrative thought of aggressive and non aggressive children: A cultural comparison. Paper presented at the IX European Conference on Developmental Psychology, Spetses, Greece.

Smorti, A., Ortega, R., Ortega-Rivera, J. \& Pagnucci, S. (2001, March). Narrative Thought and Theory of Mind in children and Adolescents involved in Bully-victim troubles. Paper presented at the International Conference on Violence in Schools and Public Policies, Paris, France.

Smorti, A., Ortega-Rivera, J., Ortega, R. \& Pagnucci, S. (2005). Adolescents involved in bully-victim relationships. The Journal of School Violence 4 (1), 5-27.

Stipek, D.J. \& DeCotis, K. M. (1988). Children's understanding of the implications of causal attributions for emotional experiences. Child Development, 59, 1601-1910.

Sutton, J., Smith, P. K. \& Swettenham, J. (1999a.). "Social cognition and bullying: social inadequacy or skilled manipulation?" British Journal of Developmental Psychology. $17,435-450$. 
Sutton, J., Smith, P. K., \& Swettenham, J. (1999b). Bullying and "theory of mind": a critique of the "social skills deficit" view of anti-social behaviour. Social Development, 8(1), $117-127$. 


\title{
APPENDIX
}

\section{Discrepant Story Task (DST)}

\author{
PROGRESSIVE STORIES
}

\section{Aggressive--Neutral (A-N)}

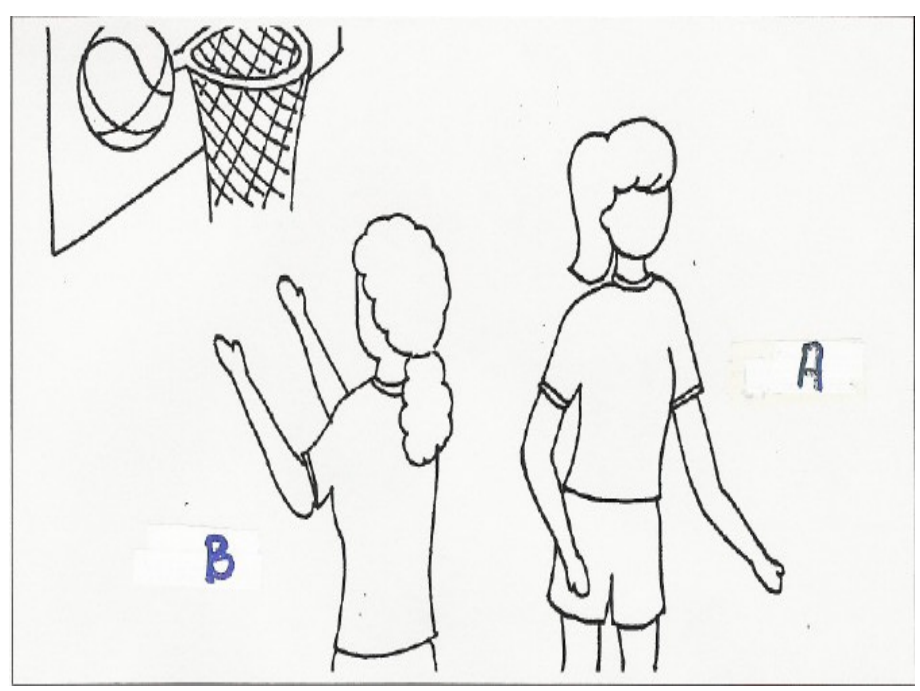

A is a spiteful boy who teases John each time he fails to net the ball when playing basketball. One day, B missed the net during a game and A continued to play on without saying anything to him.

\section{Aggressive-Prosocial (A-P)}

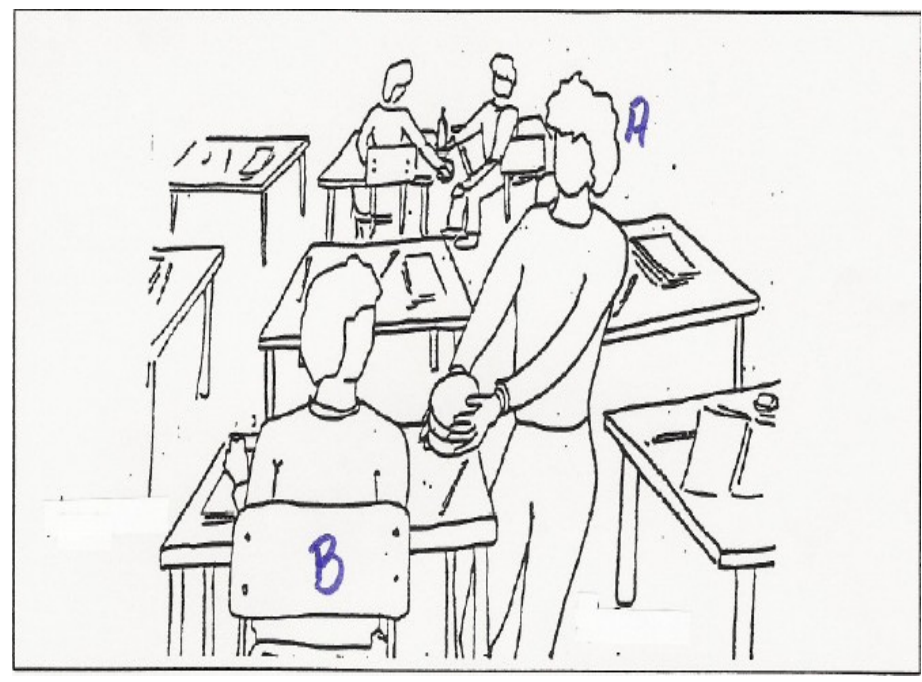

A is a very restless boy/girl. When s/he's at school, s/he often takes things from his/her classmates, especially from B, on whom s/he plays lots of nasty tricks. One day, during recess, A sees B sitting at his/her desk, goes up to him/her, and offers him/her a snack. 


\section{Neutral-Prosocial (N-P)}

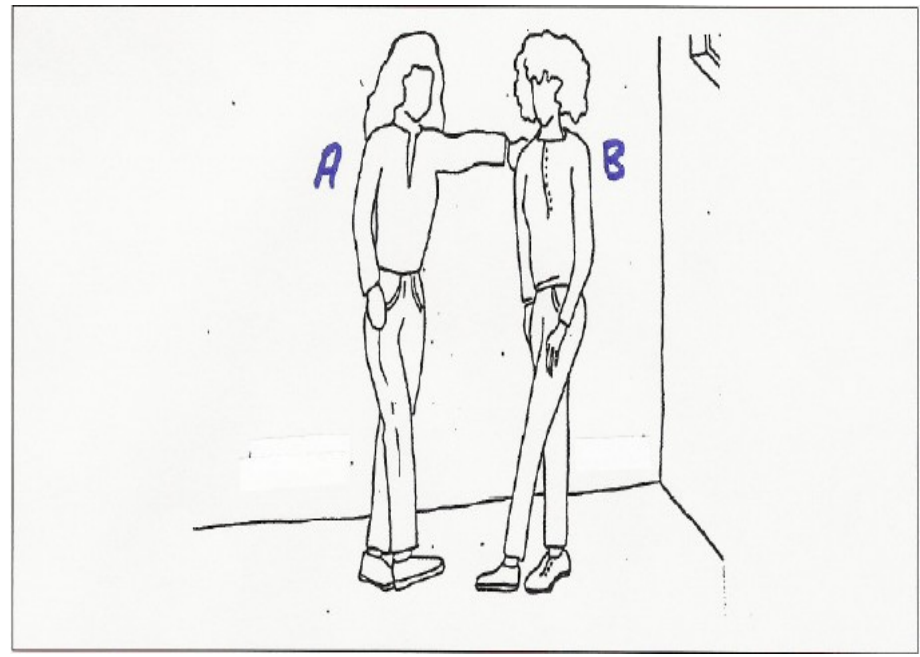

$A$ and $B$ are in the same class together but their desks are situated far apart, and they don't get many chances to talk to each other. When they leave school, A goes in one direction and B in another. Halfway through the school year, they hardly know each other. One day, A goes up to B and invites him/her to his/her house to spend the afternoon together.

\section{REGRESSIVE STORIES}

\section{Neutral--Aggressive (N-A)}

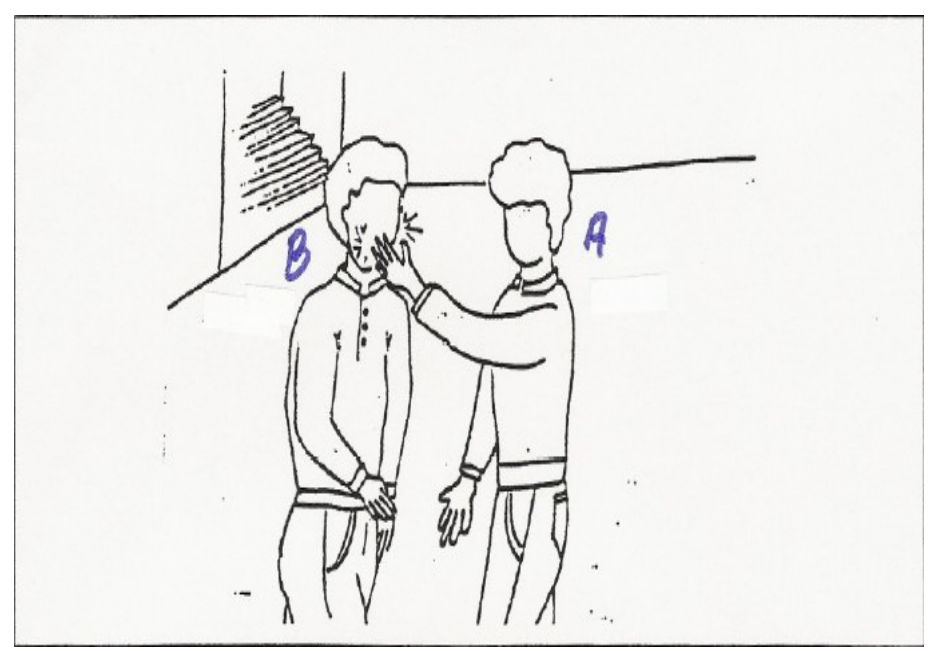

A and B are classmates but don't spend much time together because they both have their own groups of friends. They therefore don't usually talk to each other during recess. One day at school, A goes up to B and slaps him/her. 


\section{Prosocial-Aggressive (P-A)}

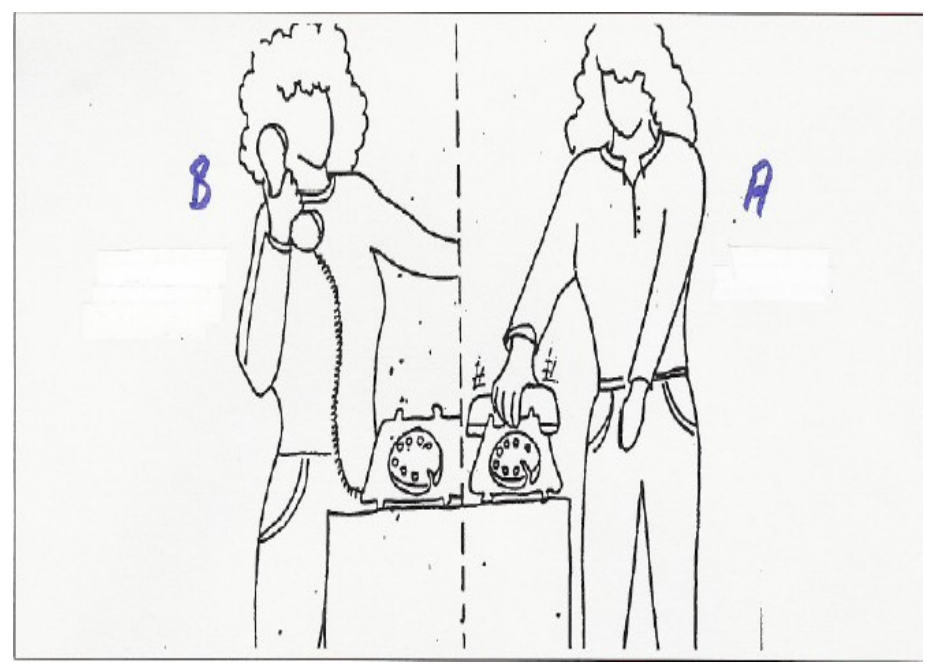

A is a very generous boy/girl and if one of his/her classmates needs help, s/he's always willing to help out. One afternoon, it just so happens that B hasn't done his/her homework, and so s/he telephones A to ask him/her to give him/her the answers. A replies by telling $\mathrm{him} /$ her not to bother him/her and then hangs up the telephone.

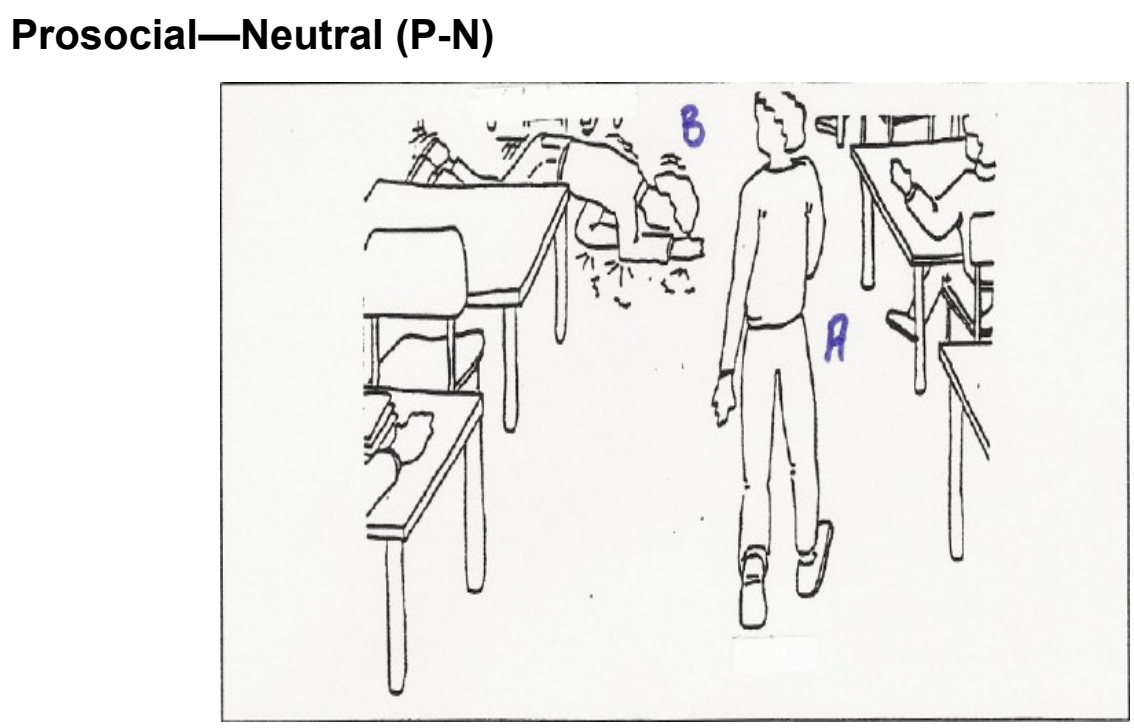

A is very nice with all his/her classmates and takes the trouble to help out whenever they need something. One day in class B trips and falls. A passes him/her and does not say anything. 
Andrea Smorti et al.

[Página en blanco por razones de paginación] 